\title{
SELF-ASSESSMENT OF CLINICAL NURSE MENTORS AS DIMENSIONS OF PROFESSIONAL DEVELOPMENT AND THE CAPABILITY OF DEVELOPING ETHICAL VALUES AT NURSING STUDENTS: A CORRELATIONAL RESEARCH STUDY
}

\author{
Authors: Brigita Skela-Savič and Alice Kiger \\ Brigita Skela-Savič, PhD, MSc, BSc, RN \\ Associate Professor, Dean \\ Faculty of Health Care Jesenice \\ Adress and other data: \\ Faculty of Health Care Jesenice \\ Spodnji Plavž 3 \\ 4270 Jesenice, Slovenia \\ Phone Number: 0038645869360 \\ Fax Number: 0038645869363 \\ Email Address: bskelasavic@fzi.si
}

Alice Kiger, PhD, Honorary Senior Lecturer, Retired Director, Advanced Studies in Nursing \& Midwifery, Division of Applied Health Sciences, University of Aberdeen, Scotland, and Associate Professor, Faculty of Health Care Jesenice, Slovenia

\section{Acknowledgements}

The paper presents, in part, the results of a broader non-profit development project entitled "Advance level of knowledge for quality in clinical mentorship - professional ethics and continuously professional development". The project was financed by the Ministry of Higher Education, Science and Sport of the Republic of Slovenia (contract no. 3211-11-000263, the number of project OP RCV_VS-11-14). The members of development group of the project were: Brigita Skela-Savič (leader), Karmen Romih, Sanela Pivač, Katja Skinder Savić and Andreja Prebil. The research report for the entire project is available on the online bibliographic database COBIB.si, at the Faculty of Health Care Jesenice and at the Ministry of Higher Education, Science and Sport of the Republic of Slovenia. 


\title{
Self-assessment of clinical nurse mentors as dimensions of professional development and the capability of developing ethical values at nursing students: A correlational research study
}

\begin{abstract}
Introduction: The implementation of clinical mentoring is an essential part of professionalism in nursing. Providing adequate training for mentors, fostering a positive mentorship culture and establishing the necessary operational procedures for ensuring mentorship quality are the keys to effective clinical mentoring of nursing students.
\end{abstract}

Purpose: The purpose of the research was to explain different dimensions of clinical mentors' professional development and their capability of developing ethical values in nursing students. Methods: A non-experimental quantitative research design was employed, and data were collected by means of a questionnaire administered to the population of clinical mentors $(\mathrm{N}=$ 143). The questionnaire was developed on the basis of a literature review. The total number of questions was 36. Descriptive statistics were used, and bivariate analysis, factor analysis, correlation analysis and linear regression analysis were performed.

Results: The professional development of clinical nurse mentors was explained $\left(\mathrm{R}^{2}=0.256\right)$ by career advancement $(\mathrm{p}=0.000)$, research and learning $(\mathrm{p}=0.024)$ and having a career development plan $(p=0.043)$. Increased professional self-confidence $\left(R^{2}=0.188\right)$ was explained by career advancement $(\mathrm{p}=0.000)$ and the time engaged in record keeping $(\mathrm{p}=$ 0.028). Responsibility for the development of ethical values in nursing students $\left(R^{2}=0.145\right)$ was explained by the respondents' level of education $(\mathrm{p}=0.020)$ and research and learning $(\mathrm{p}$ $=0.024)$. Applying ethical principles and norms into practice $\left(\mathrm{R}^{2}=0.212\right)$ was explained by self-assessed knowledge in ethics $(p=0.037)$ and research and learning $(p=0.044)$.

Conclusions: Clinical nurse mentors tended to lack a career development plan, had low work time spent on research and insufficiently participated in education and training activities, which turned out to be significant explanatory factors of their professional development and their capability of developing ethical values in nursing students. The research showed that nursing and higher education managers often failed to assume responsibility for the professional development of clinical nurse mentors.

\section{INTRODUCTION}

The implementation of clinical mentoring is essential to student nurses' learning. This relates not only to their development of practical skills but also to their development of professionalism, which incorporates interactive skills and ethical competence. Hegenbarth et al. (2015) cites that clinical training consolidates the students' knowledge and socializes them into the profession.

Opportunities for ongoing professional development of clinical nurse mentors is a frequently occurring comment throughout literature (Jokelainen et al., 2011a; Waldock, 2010; Cangelosi et al., 2009; Johnston and Mohide, 2009; Baldwin et al., 2014). Providing adequate training for mentors, fostering a positive mentorship culture and establishing the necessary operational procedures for ensuring mentorship quality are the keys to effective clinical mentoring of nursing students. Baldwin et al. (2014) summarized that there is wide agreement that nursing students view clinicians as influential role models for their practice and that there is a need for consistent continuing professional development for clinicians who assume this role in order to ensure quality experiences for students.

\section{Background/Literature}

Providing clinical mentoring for students is part of nursing professionalism, which, in turn, reflects how nurses view their work and serves as an important indicator for ensuring patient 
safety and high quality care. Professionalism and the formation of a positive professional identity constitute key elements influencing the development of future nursing graduates (Shakespeare and Webb, 2008).

Anderson (2011) suggests that good clinical nurse mentors encourage students to gain knowledge and clinical experience, treat them as individuals, recognize different learning stages, demonstrate practical nursing interventions and involve students in professional clinical teams. A literature review by Wilkes (2006) found that for students, mentors represent an inspiration and are role models who not only take care of patient needs, but also student needs. Bailey and Tuohy (2009) emphasize that, for the learning process to be successful, students need support from teachers, relevant skills, prior experimental learning and required theoretical knowledge, among other things.

From a systematic review, Jokelainen et al. (2011a) sought a unified description of student mentoring. Their review identified characteristics of clinical mentoring such as creating a supporting learning environment, enabling students' individual learning processes, strengthening students' professionalism, helping them develop their professional identities and improving nursing students' professional competence. Both professionalism and the formation of a positive professional identity constitute key elements influencing the development of future nursing graduates.

An essential element of the knowledge and skills nursing students must acquire is the development of competencies in moral and ethical decision-making in a clinical setting. The relationships and interactions between students and their educators have the potential to influence the development of students' ethical values. From a study based on findings from 19 focus groups, Doane (2002) states that health providers are responsible for supporting and encouraging nurses to make ethical decisions, thereby developing their professional identity, self-concept and self-esteem as moral decision makers. Research by Elpern et al. (2005) and Lützen et al. (2010) revealed that nurses experienced moral distress when they could not take a course of action they believed to be best for the patient, or, generally speaking, when their ability to influence the moral and ethical decision-making in a clinical setting was insufficient or extremely restricted, which in turn impacted on their personal and professional selfperceptions. This suggests that student nurses need support in developing strategies to contend with such situations. Nolan and Markert (2002) recognized in their longitudinal study that students did not consider their clinical experience to have been especially significant in their growing ethical understanding. Discussing the revision of a "code of ethics for nurse educators", Rosenkoetter and Milstead (2010) have argued that the role of educators (instructors, clinical mentors) is crucial, as they represent not only role models for students, but also a source of reliable information and encouragement to critically evaluate their own ethical decisions and the ethical decision-making of those they work with throughout their nursing practice.

Results of a phenomenographic study conducted with British and Finnish mentors by Jokelainen et al. (2011b) suggested that effective student mentoring in the clinical setting can only be ensured by providing adequate training for mentors, fostering a positive mentorship culture and establishing the necessary operational procedures for ensuring mentorship quality. Hutschings et al. (2005) suggest that mentors require more support from educators who should be more frequently in contact with clinical settings, and Jokelainen et al. (2011b) find that mentors need to reserve more time for mentoring students. According to Waldock (2010), in a literature-based discussion piece, one of the most common concerns reported by clinical nurses engaged in student supervision is the lack of support at different levels, ranging from nursing school leaders and health provider managers, to colleagues in the clinical setting. A literature review by $\mathrm{Lu}$ et al. (2005) found that supervisory support was correlated with nurses' job 
satisfaction. If nurses have a higher commitment to their profession, they are more satisfied with their job (Hampton and Hampton, 2004).

In a systematic review of 23 research articles that focused on the term 'mentoring', Jokelainen et al. (2011a) found that decisive factors in ensuring effective mentoring programs for nursing students include the characteristics and management of health care organizations, as these play a crucial role in ensuring the necessary resources and systematic training for mentors. Findings of a study carried out by Çelik and Hisar (2012), among 531 nurses working at a range of hospitals in Turkey, suggest that nursing educators and managers must encourage nurses to participate in education and training programs, while also developing various programs designed to expand nurses' access to education.

Other studies (e.g. Huybrecht et al., 2011) have stressed the importance of training opportunities for clinical mentors working with nursing students. Continuing education, or continuing professional development (CPD), is extremely important for increasing the level of professionalism.

\section{Goal of research}

The goal of the research was to explain different dimensions of clinical mentors' professional development and their capability of developing ethical values in nursing students.

\section{METHODS}

A non-experimental quantitative research design was employed.

\section{Description of research instrument}

A structured questionnaire was used for the survey. The survey was conducted as part of a FHCJ development project (Skela-Savič et al., 2011). Variables were designed based on a review of research by various authors in professional ethics and CPD (Paulsen, 2011; Erdil and Korkmaz, 2009; Hunink et al., 2009; Hallin and Danielson, 2008; Björkström et al., 2008; Rassin, 2008). The questionnaire included demographic items (4 closed-ended questions), items related to the respondents' level of education, professional development, working time spent for different tasks (communication, documentation, research, clinical mentoring and health education) and knowledge of ethics (17 closed-ended questions). The final part of the questionnaire consisted of two content-related sets of questions: dimensions of professional development (6 closedended questions, Cronbach's $\alpha=0.780$ ) and the development of ethical values in nursing students (9 closed-ended questions, Cronbach's $\alpha=0.828$ ). Respondents were asked to indicate, on a 5-point Likert scale, their level of agreement with two content-related sets of questions, ranging from the lowest (1) to the highest (5) level of agreement $(1=$ Strongly disagree, $2=$ Disagree, $3=$ Neither agree nor disagree, $4=$ Agree, $5=$ Strongly agree). The total number of questions was 36 .

\section{Data collection and processing}

The study was conducted between June and September 2012 and adheres to the principles set forth in the Declaration of Helsinki. Prior permission was obtained for the distribution of questionnaires from all participating health care institutions and from the Committee for Scientific Research at the Faculty of Health Care Jesenice. Data collection was anonymous; respondents were free to decline participation. The person responsible for each particular clinical learning centre distributed the questionnaires among the departments and units. Respondents were given 10 days to return completed questionnaires to the agreed place.

The obtained data were analysed using the statistical software SPSS 18.0. Internal consistency for the total set results was assessed using Cronbach's alpha. Basic descriptive analysis, a chi-square test, correlation analysis (Pearson's correlation coefficient), Principal 
Axis Factor Analysis, Varimax with Kaiser Normalization, and linear regression were performed. In conducting the Factor Analysis, recommendations by Sapnas and Zeller (2002) were used for the number of respondents per item. The level of statistical significance was set at $p<0.05$.

\section{Sample description}

The sample of respondents included clinical mentors (registered nurses) across twenty different health care settings in Slovenia, including health care institutions and long-term care facilities. In the 2011/12 academic year, the respondents participated in mentoring first Bologna cycle nursing students at the Faculty of Health Care Jesenice. The questionnaires were distributed to a total of 292 clinical nurse mentors. Of these, 143 were returned (49\%). The demographic characteristics of the sample are shown in Table 1. The majority of respondents fell within the 26-33 age group (30.8\%), had a professional higher education (83.9\%) and had been employed for more than 10 years $(43.4 \%)$. Moreover, most of the clinical mentor respondents were employed in tertiary health care $(52.4 \%)$.

\section{RESULTS}

\section{Characteristics of respondents and their places of employment}

The amount of time respondents engage in direct and indirect nursing activities during a typical 8 -hour workday added up to 100 percent. The activity in which respondents engage the most is communication with patients $(M=29.9 ; S D=15.4)$, followed by record keeping $(M=21.7$; $\mathrm{SD}=12.7)$, health care counselling and education $(\mathrm{M}=14.1 ; \mathrm{SD}=8.0)$, mentorship to students $(\mathrm{M}=12.8 ; \mathrm{SD}=7.9)$, communication with families of patients $(\mathrm{M}=10.1 ; \mathrm{SD}=6.4)$, other $(\mathrm{M}$ $=8.3 ; \mathrm{SD}=14.3)$ and research $(\mathrm{M}=2.7 ; \mathrm{SD}=4.0)$.

In terms of career development opportunities, 39 respondents $(27.3 \%)$ reported having agreed on their career development plan with the employer, 67 (46.9\%) reported not having a career development plan, and 34 (23.8\%) said they did not know. The answer 'I don't know' was more common in respondents aged up to 33 years $\left(\chi^{2}=16.496 ; p=0.011\right)$. A total of $30.1 \%$ of respondents believe that career advancement always influences their job satisfaction level, compared to $56.6 \%$ of respondents who believe that it sometimes influences it and $10.5 \%$ of respondents who believe it does not influence it at all. No significant differences were established for the demographic data.

Next, we were interested in how many days respondents participated in education and training programs provided by their employer over the past year. The majority of respondents $(51 \%)$ received $1-3$ days of additional training, 31.5\% received 4-9 days, 15 respondents $(10.5 \%)$ participated in no education/training programs, and 8 respondents $(5.6 \%)$ received 10 days or more. Respondents aged under 33 participated in education and training significantly less compared to their older peers $\left(\chi^{2}=18.923 ; p=0.026\right)$. On average, respondents participated in education/training programs for 1.9 days over the past year $(\mathrm{SD}=2.2)$, with those employed under 5 years participating the fewest days $(\mathrm{F}=6.692 ; p=0.002)$.

With respect to the topic of education/training programs, respondents most often participated in programs from their own area of work $(\mathrm{N}=97)$, followed by programs in communication skills $(\mathrm{N}=58)$, ethics $(\mathrm{N}=42)$, legislation $(\mathrm{N}=31)$, information technology $(\mathrm{N}=17)$, and research $(\mathrm{N}=14)$. A follow-up report on the education/training program was delivered in the workplace by 88 respondents, while 51 failed to provide a report. The likelihood of delivering a follow-up report is more common among the younger age group $\left(\chi^{2}=9.923 ; p\right.$ $=0.019)$, and is negatively correlated with the duration of an education/training program $(\mathrm{r}=-$ $0.310, \mathrm{p}<0.01)$. 
When asked to indicate the number of days they had spent participating in mentor preparation programs over the past three years, the majority of respondents selected $1-3$ days $(\mathrm{N}=74)$, followed by zero days $(\mathrm{N}=50), 4-9$ days $(\mathrm{N}=14)$ and 10 days or more $(\mathrm{N}=2)$. A longer period of employment was the reason for a greater amount of training for mentors received $\left(\chi^{2}\right.$ $=19.065 ; p=0.004)$. Moreover, the amount of training in communication skills and the total number of days spent on education/training programs correlated positively with the amount of training for mentors $(\mathrm{r}=0.172, p<0.05$ and $\mathrm{r}=0.195, p<0.05$, respectively).

On a 5-point grading scale ( $1=$ Unsatisfactory, $5=$ Excellent $)$, respondents self-assessed their knowledge of ethics in health care with a mean value of $3.5(\mathrm{SD}=0.8)$. Here, respondents aged under 40 self-assessed their knowledge with a lower mean value $(\mathrm{F}=2.859 ; p=0.039)$. Knowledge of ethics corresponded positively with the age of respondents $(\mathrm{r}=0.236, p<0.01)$, the time respondents spent working with nursing students $(\mathrm{r}=0.367, p<0.01)$, the number of education/training days received $(\mathrm{r}=0.171, p<0.05)$, receiving education in ethics $(\mathrm{r}=0.193$, $p<0.05)$ and legislation $(\mathrm{r}=0.217, p<0.01)$ and participation in mentor preparation programs $(\mathrm{r}=0.241, p<0.01)$. A negative correlation was established for having a personal career development plan $(r=-0.193, p<0.05)$.

The capability of developing ethical values in nursing students on a 5-point Likert grading scale $(1=$ Unsatisfactory, $5=$ Excellent $)$ was self-assessed with a mean value of $3.4(\mathrm{SD}=0.8)$, with younger respondents (under 40$)$ assigning a significantly lower value $(\mathrm{F}=3.113 ; p=$ 0.029). A positive correlation was established between the capability of developing ethical values and the total student mentoring time $(\mathrm{r}=0.335, p<0.01)$, the total number of education/training days received $(\mathrm{r}=0.195, p<0.05)$, education in legislation $(\mathrm{r}=0.270, p<$ $0.01)$, mentor preparation programs $(\mathrm{r}=0.218, p<0.05)$, and self-assessed knowledge in ethics $(\mathrm{r}=0.725, p<0.01)$. Conversely, a negative correlation was established for agreement with the statement that career advancement influences job satisfaction $(r=-0.172, p<0.05)$.

The respondents believe that research activities and additional education/training programs could always $(\mathrm{N}=65)$ or sometimes $(\mathrm{N}=75)$ contribute to the development of nursing. A weak positive correlation was established for the variable with the time respondents spend engaged in record keeping $(\mathrm{r}=0.244, p<0.01)$, and for agreement with the statement that career advancement influences the level of job satisfaction $(\mathrm{r}=0.247, p<0.01)$, whereas a weak negative correlation was found to exist for the time spent engaged in health care counselling $(\mathrm{r}$ $=-0.188, p<0.05)$ and in research $(\mathrm{r}=-0.167, p<0.05)$.

\section{Dimensions of professional development}

The results in Table 2 show the respondents' opinions on different dimensions of professional development. Respondents aged under 25 indicated a lower agreement with the statement that professional development influences the development of nursing $(\mathrm{F}=3.388 ; p=0.020)$. The highest importance to professional development in terms of its influence on job performance and results was assigned by respondents who have been employed under 5 years $(\mathrm{F}=3.079 ; p$ $=0.049$ ).

Analysis of statement dependence revealed that factor analysis should be conducted (KMO $=0.810, p=0.000)$. Principal Axis Factor Analysis and Varimax with Kaiser Normalization yielded two factors (Table 2) which explained $71.972 \%$ of the total variance: (1) 'Professional development and its positive effects on job performance' and (2) 'Increased self-confidence and other effects of professional development', explaining $54.875 \%$ and $17.115 \%$ of the total variance, respectively.

\section{Development of ethical values in nursing students}

The results in Table 3 show respondents' self-assessment on mentoring nursing students. It was revealed that, for transferring ethical norms (Code of Ethics, acts and declarations) into practice, 
respondents self-assessed their work with an average level of agreement. With respect to age, younger respondents under 33 had lower mean values for the following variables: adherence to the Code of Ethics $(\mathrm{F}=3.038 ; p=0.031)$, providing information on acts and declarations $(\mathrm{F}=$ $4.656 ; p=0.004)$ and transferring theory into practice $(\mathrm{F}=3.988 ; p=0.009)$. Respondents employed 6-10 years assigned the least importance to transferring ethical norms into practice $(\mathrm{F}=4.458 ; p=0.013)$.

The importance of resolving ethical dilemmas was significantly lower in respondents aged under $33(\mathrm{~F}=2.832 ; p=0.041)$, as was the importance of their own unethical behavior on the development of ethical values in nursing students $(\mathrm{F}=3.055 ; p=0.031)$.

Analysis of statement dependence revealed that factor analysis should be conducted (KMO $=0.809, \mathrm{p}=0.000)$. Principal Axis Factor Analysis and Varimax with Kaiser Normalization yielded two factors which explained $66.500 \%$ of the total variance: (1) 'Responsibility for the development of ethical values in nursing students' and (2) 'Applying ethical principles and norms into practice', explaining $39.068 \%$ and $27.432 \%$ of the total variance, respectively.

Table 4 shows the correlation analysis results for the four obtained factors, demographic characteristics, and the professional characteristics of respondents. According to Pallant's (2010) scale, the obtained correlations would be considered weak $(r=0.10-0.29)$ and moderate $(\mathrm{r}=0.30-0.49)$; there were no strong correlation measures $(\mathrm{r}=0.50-1.0)$. Statistically significant correlations were employed for the production of four regression models (Table 5).

\section{Regression analysis}

For the set 'Dimensions of professional development', we wanted to explain two dependent variables. It was revealed that three independent variables explained $25.6 \%$ of total variation for the first dependent variable, 'Professional development and its positive effects on job performance'. The second dependent variable, 'Increased self-confidence and other effects of professional development', was explained in $18.8 \%$ by two independent variables.

Two regression models were produced for the set 'Development of ethical values in nursing students'. The first dependent variable, 'Responsibility for the development of ethical values in nursing students', was explained in $14.5 \%$ by two independent variables. The second dependent variable, 'Applying ethical principles and norms into practice', was explained in $21.2 \%$ by two independent variables. Results are in Table 5.

\section{DISCUSSION}

The study examined selected professional dimensions of clinical mentors and their work setting, their understanding of career development, and their capability of developing ethical values in nursing students.

\section{Lack of professional development}

Our results showed that nursing managers often fail to assume responsibility for the professional development of clinical mentors. Namely, just under a third of respondents had an established career development plan agreed on with their employer, which was even rarer in younger respondents and those who have been employed for a shorter period of time. Importantly, the results of the regression analysis revealed that this variable significantly explained the positive work setting influences on the respondents' professional development. Moreover, the employee satisfaction level as a result of career advancement was twice as significant an explanatory factor in the regression model of professional development dimensions. Results confirmed some previous research (Waldock, 2010; Huybrecht et al., 2011; Jokelainen et al., 2011b; Hallin and Danielson, 2008; Tourangeau et al., 2010).

There is vast opportunity for improvement in the field of human resource management in nursing in Slovenia. Nursing managers fail to sufficiently include clinical nurse mentors in their 
professional development, leading to a culture of overall inadequate involvement of employees in the management of health care institutions. Similar conclusions were reached previously in some Slovenian studies. Skela-Savič and Robida (2013) showed that the inclusion of employees in their development and in the complex operations of the organization was low, Skela-Savič and Pagon (2008) showed that leaders should be the ones to assume a key role in promoting the involvement of individuals and their knowledge and study by Lorber and Skela-Savič (2012) confirmed that Slovenian hospitals are not taking full advantage of the intellectual capital and experience of their employees.

\section{Importance of research work and learning}

The regression analysis results have pointed also to the other causal relations between the dimensions of clinical nurse mentors' professional development and their capability of developing ethical values in nursing students. As indicated, respondents' agreement with the statement that research and learning contribute to the development of nursing significantly explains three dependent variables and almost explains one of them. This result testifies that nurse mentors are aware of the importance of research in nursing, but we recognize that they do not spend a lot of working time on research. The low percentage of work time spent on research is worrying, and these findings confirm the results of previous studies in Slovenia which showed that nursing research in Slovenia is underdeveloped (Strojan et al., 2012; SkelaSavič, 2009). In contrast, several previous study results have revealed low awareness of the importance of research and a lack of willingness to conduct research in nursing (Skela-Savič, 2014; Short, 2008; McCloskey, 2008; McCance et al. 2007; Green et al., 2006; Segrott et al., 2005). Regarding the topic of education/training programs, our results have revealed that most programs covered respondents' own specialized areas of work. Yet, if nursing managers wish to achieve significant professional advancement of nursing, education and training programs must also be provided in elements contributing to greater professionalism.

Also interesting is that, according to mentor respondents, career advancement influences the level of job satisfaction, yet the results show that only a third of respondents have a career development plan agreed on with their employer. Thus, one of the key findings of our research is that clinical nurse mentors tend to lack a career development plan, reflected by worrying selfassessment results for knowledge and skills required to perform tasks in the researched work dimensions. Particularly concerning are the outcomes for younger clinical mentors-these represent a third of the sample - who are given fewer education/training opportunities and spend a lower than average amount of the workday engaged in research activities.

\section{Knowledge in ethics have gaps}

Clinical mentors are crucial in the development of ethical values in nursing students. On average, mentors self-assessed their knowledge of ethics as being between good and very good. Consequently, comparable results were obtained for the self-assessment of the ability to develop ethical values in nursing students. In terms of improving mentors' competence for developing ethical values, significant variables included the time spent mentoring students, and a higher number of education/training days received in ethics, legislation, and mentoring.

Despite self-assessing their knowledge in ethics as being good or very good, clinical mentors' opinions on the development of ethical values in nursing students revealed a sub-par implementation of different activities. Of course, the question which arises is what kind of role models clinical mentors are to nursing students, if they self-assessed their knowledge as having gaps. Rosenkoetter and Milstead (2010) stress the role of all educators in nursing, as they not only represent role models for students, but also a source of reliable information and encouragement to critically evaluate their own ethical decisions and the ethical decision-making of those they work with during their nursing practice. 
Here, the responsibility clearly lies with the managers of health care institutions - they have to provide clinical mentors with the opportunity to develop their ethical behavior and, thereby, also their personal identity, self-concept, and self-esteem as moral decision makers. As indicated, nursing managers should keep in mind that nurses who have a higher commitment to their profession are more satisfied with their job (Lu et al., 2005; Hampton and Hampton, 2004; Blegen, 1993).

Several authors (Hunink et al., 2009; Vanlaere and Gastmans, 2007) have stressed the importance of incorporating ethical theory into nursing practice. The best didactic tools for achieving this goal include fostering discussions between clinical mentors and nursing students, and encouraging students to reflect on the implementation, methods, possible issues, and dilemmas connected with clinical nursing practice. Our research showed that mentors need to have more time for working with students. Nursing and Midwifery Council standards (2010) for undergraduate education recommend that $40 \%$ of mentors' working time is available for students, whereas mentors in our study spent $12 \%$ of their working time engaged in mentoring.

\section{Role of higher education institutions}

In advancing professionalism, higher education institutions training clinical mentors in student supervision may play an important role by offering programs covering the core elements of professionalism in nursing such as research, evidence-based practice, ethics, the importance of theoretical knowledge for work autonomy, etc. According to the results, half of mentor respondents had participated in training programs from this field over the past three years, but a third did not. This cannot be seen as an encouraging result, especially because the Faculty of Health Care Jesenice organizes, free of charge, at least one annual two-day seminar for clinical mentors. Here, the Faculty is facing the issue of insufficient participation in the seminars offered, at least partly due to a lack of encouragement from nursing managers. This issue has been described by authors such as Gould et al. (2007).

In the future, additional activities and efforts are needed for the cooperation of nursing school leaders and nursing managers, so that they can assume responsibility for ensuring highquality clinical mentoring. Baldwin et al. (2014) recognized that Nurse academics have a greater role than just conveying theoretical knowledge. Enthusiasm for, and positive attitude towards nursing demonstrated in the classroom have a powerful impact on nursing students' understanding of professional behaviour. Importantly, we should ask ourselves how successful we are at teaching professionalism in Slovenian nursing programs and what can be done to further develop professionalism in the career planning of a clinical nurse mentor. According to Worthington et al. (2013), professional identity is directly related to student retention in the nursing program. It is important to adequately measure professional identity in nursing students for the purpose of monitoring and identifying students who are at risk of leaving nursing programs. In Slovenia, this is increasingly becoming a challenge during the entrance examination procedures for nursing programs and in monitoring students throughout their studies. At the moment, before commencing their nursing program, future RNs in Slovenia are not required to take a personal quality assessment test. In studying the professional qualities of nursing students, Pitt et al. (2014) found that personal qualities were unchanged after three years, which suggests the importance of incorporating the assessment of these qualities into the recruitment and selection of nursing students.

Study limitations include the sample size. Research included only the self-assessment of clinical mentors. Naturally, more data would be obtained if nursing students were to assess the performance of their mentors in the researched areas, which is a possible future study in this field.

\section{CONCLUSION}


The research results revealed the importance of clinical mentors' career development for fostering professional development. One of the key findings of our research is that clinical nurse mentors tend to lack a career development plan, reflected by worrying self-assessment results for knowledge and skills required to perform tasks in the researched work dimensions and CPD. In terms of improving mentors' competence for developing ethical values, significant variables included the time spent mentoring students, and a higher number of education/training days received in ethics, legislation, and mentoring. Result also testifies that nurse mentors are aware of the importance of research in nursing, but we recognize that they do not spend a lot of working time on research and working with students. Particularly concerning are the outcomes for younger clinical mentors - these represent a third of the sample - who are given fewer education/training opportunities and spend a lower than average amount of the workday engaged in research activities. For conclusion, we recognized that nursing managers in Slovenia do not assume enough responsibility for the professional development of clinical mentors. Nursing academics should ask themselves how successful they are at teaching professionalism in nursing programs and what they can do to further enhance professionalism by developing career plans for clinical nurse mentors. The responsibility for ensuring that lies with the nursing school leaders and nursing managers in health care institutions.

\section{References}

Anderson, L., 2011. A learning resource for developing effective mentorship in practice. Nurs. Stand. 25 (51), 48-56.

Bailey, M.E., Tuohy, D., 2009. Student nurses' experiences of using a learning contract as a method of assessment. Nurse Educ. Today 29 (7), 758-762.

http://dx.doi.org/10.1016/j.nedt.2009.03.012

Baldwin, A., Mills, J., Birks, M., Budden, L., 2014. Role modeling in undergraduate nursing education: An integrative literature review. Nurse Educ. Today 34 (6), e18-e26.

http://dx.doi.org/10.1016/j.nedt.2013.12.007

Bjorkstrom, M.E., Athlin, E.E., Johansson, I.S., 2008. Nurses' development of professional self - from being a nursing student in a baccalaureate programme to an experienced nurse. $J$. Clin. Nurs. 17 (10), 1380-1391. http://dx.doi.org/10.1111/j.1365-2702.2007.02014.x.

Blegen, M.A., 1993. Nurses' job satisfaction: A meta-analysis of related variables. Nurs. Res. $42(1), 36-41$.

Cangelosi, P.R., Crocker, S., Sorrell, J.M., 2009. Expert to novice: clinicians learning new roles as

clinical educators. Nurs. Educ. Perspect. 30 (6), 367-371.

Çelik, S., Hisar, F., 2012. The influence of the professionalism behaviour of nurses working in health institutions on job satisfaction. Int. J. Nurs. Practice 18 (2), 180-187. http://dx.doi.org/10.1111/j.1440-172X.2012.02019.x.

Doane, G.A.H., 2002. Am I still ethical? The socially-mediated process of nurses' moral identity. Nurs. Ethics 9 (6), 623-635.http://dx.doi.org/10.1191/0969733002ne556oa 
Elpern, E.H., Covert, B., Kleinpell, R., 2005. Moral distress of staff nurses in a medical intensive care unit. Am. J. Crit. Care 14 (6), 523-530.

Erdil, F., Korkmaz, F., 2009. Ethical problems observed by student nurses. Nurs. Ethics 16 (5), 589-598. http://dx.doi.org/10.1177/0969733009106651.

Green, B., Segrott, J., Hewitt, J., 2006. Developing nursing and midwifery research capacity in a university department: case study. J. Adv. Nurs. 56 (3), 302-313.

http://dx.doi.org/10.1111/j.1365-2648.2006.04022.x.

Gould, D., Drey, N., Berridge, E.J., 2007. Nurses' experiences of continuing professional $\begin{array}{lllll}\text { development. } & \text { Nurse } & \text { Educ. } & \text { Today } & \text { 602-609. }\end{array}$ http://dx.doi.org/10.1016/j.nedt.2006.08.021.

Hallin, K., Danielson, E., 2008. Registered Nurses' perceptions of their work and professional development. J. Adv. Nurs. 61 (1), 62-70.

Hampton, G.M., Hampton, D.L., 2004. Relationship of professionalism, rewards, market orientation and job satisfaction among medical professions: The case of certified nursemidwives. Journal of Business Research 57 (9), 1042-1053. 10.1016/S0148-2963(02)003569

Hegenbarth, M., Rawe, S., Murray, L., Arnaert, A., Chambers-Evans, J., 2015. Establishing and maintaining the clinical learning environment for nursing students: A qualitative study. Nurse Educ. Today 35 (2), 304-309. http://dx.doi.org/10.1016/j.nedt.2014.10.002

Hunink, G., van Leeuwen R., Jansen, M., Jochemsen, H., 2009. Moral Issues in Mentoring Sessions. Nurs. Ethics 16 (4), 487-498. http://dx.doi.org/10.1177/0969733009104611.

Hutchings, A., Williamson, G.R., Humphreys, A., 2005. Supporting learners in clinical practice: capacity issues. J. Clin. Nurs 14 (8), 945-955. http://dx.doi.org/10.1111/j.13652702.2005.01239.x

Huybrecht, S., Loeckx, W., Quaeyhaegens, Y., De Tobel, D., Mistiaen, W., 2011. Mentoring in nursing education: Perceived characteristics of mentors and the consequences of mentorship. Nurs. Educ. Today. 31(3), 274-278. http://dx.doi.org/10.1016/j.nedt.2010.10.022

Jokelainen, M., Turunen, H., Tossavainen, K., Jamookeeahan, D., Coco, K., 2011a. A systematic review of mentoring nursing students in clinical placements. Clin. Nurs. 20 (19/20), 2854-2867. http://dx.doi.org/ 10.1111/j.1365-2702.2010.03571.x.

Jokelainen, M., Jamookeeah, D., Tossavainen, K., Turunen, H., 2011b. Building organizational capacity for effective mentorship of pre-registration nursing students during placement learning: Finnish and British mentor's conceptions. Int. J. Nurs. Pract. 17 (5), 509-517. http://dx.doi.org/10.1111/j.1440-172X.2011.01964.X

Johnston, C., Mohide, E.A., 2009. Addressing diversity in clinical nursing education: support for preceptors. Nurse Educ. Pract. 9 (5), 340-347.

http://dx.doi.org/10.1016/j.nepr.2008.08.005 
Lorber, M., Skela-Savič, B., 2012. Job satisfaction of nurses and identifying factors of job satisfaction in Slovenian hospitals. Croat. Med. J. 53 (3), 263-270. 10.3325/cmj.2012.53.263

Lu, H., White, E.A., Bariball, L., 2005. Job satisfaction among nurses: A literature review. Int. J. Nurs. Stud. 42 (2), 211-227.

Lützén, K., Blom, T., Ewalds-Kvist, B., Winch, S., 2010. Moral stress, moral climate and moral sensitivity among psychiatric professionals. Nurs. Ethics 17 (2), 213-224. http://dx.doi.org/ 10.1177/0969733009351951.

McCance, T.V., Fitzsimons, D., Keeney, S., Hasson, F., McKenna, H.P., 2007. Capacity building in nursing and midwifery research and development: an old priority with a new perspective. J. Adv. Nurs. 59 (1), 57-67. http://dx.doi.org/10.1111/j.1365-2648.2007.04280.x

McCloskey, D.J., 2008. Nurses' perceptions of research utilization in a corporate health care system. J. Nurs. Scholarsh. 40 (1), 39-45. http://dx.doi.org/10.1111/j.1547-5069.2007.00204.x.

Nolan, P.W., Markert, D., 2002. Ethical reasoning observed: a longitudinal study of nursing students. Nurs Ethics 9 (3), 243-258. http://dx.doi.org/10.1191/0969733002ne507oa

Nursing and Midwifery Council, 2010. Standards for pre-registration nursing education. http://standards.nmc-uk.org/PublishedDocuments/Standards\%20for\%20preregistration\%20nursing\%20education\%2016082010.pdf (Accessed 28th October 2013).

Pallant, J., 2010. SPSS Survival Manual. A step by step guide to data analysis using SPSS. Fourth ed. Open University Press, McGraw Hill.

Paulsen, J.E., 2011. Ethics of caring and professional roles. Nurs. Ethics 18 (2), 201-208. http://dx.doi.org/10.1177/0969733010392302.

Pitt, V., Powis, D., Levett-Jones, T., Hunter, S., 2014. Nursing students' personal qualities: A descriptive study. Nurse Educ. Today 34 (9), 1196-1200. http://dx.doi.org/http://dx.doi.org/10.1016/j.nedt.2014.05.004.

Rassin, M., 2008. Nurses' professional and personal values. Nurs. Ethics 15 (5), 614-630. http://dx.doi.org/10.1177/0969733008092870.

Rosenkoetter, M.M., Milstead, A.J., 2010. A code of ethics for nurse educators: Revised. Nurs. Ethics 17 (1), 137-139. http://dx.doi.org/10.1177/0969733009350946.

Sapnas, K.G., Zeller, R.A., 2002. Minimizing sample size when using exploratory factor analysis for measurement. J Nurs Meas 10(2), 135-154.

Segrott, J., Mcivor, M., Green, B., 2005. Challenges and strategies in developing nursing research capacity: a review of the literature. Int. J. Nurs. Stud. 43 (5), 637-651. http://dx.doi.org/10.1016/j.ijnurstu.2005.07.011.

Shakespeare, P., Webb, C., 2008. Professional identity as a resource for talk: exploring the mentor-student relationship. Nurs. Inq. 15 (4), 270-279. http://dx.doi.org/10.1111/j.14401800.2008.00415.x. 
Short, N.M., 2008. Influencing health policy: strategies for nursing education to partner with $\begin{array}{llllll}\text { nursing } & \text { practice. } & \text { J. } & \text { Prof. } & \text { Nurs. } & \end{array}$ http://dx.doi.org/10.1016/j.profnurs.2007.10.004.

Skela-Savič, B., 2014. Are we aware of our responsibilities for the development of nursing?

Obzor. Zdr. N. 48 (1), 5-11. http://dx.doi.org/10.14528/snr.2014.48.1.12

Skela-Savič, B., Robida, A., 2013. Capacity of middle management in health-care organizations for working with people - the case of Slovenian hospitals. Hum. Resour. Health 11 (1), 18. http://dx.doi.org/10.1186/1478-4491-11-18.

Skela-Savič, B., Skinder Savić, K., Romih, K., Prebil, A., Pivač, S., 2011. Napredna znanja za kakovostno delo s študenti zdravstvene nege - poklicna etika in kontinuiran profesionalni razvoj: zaključno raziskovalno poročilo projekta: trajanje projekta 1. 6. do 5. 10. 2011. Jesenice: Visoka šola za zdravstveno nego.

Skela-Savič, B., 2009. Nursing care and research: Some factors influencing the development of nursing as a scientific discipline in Slovenia. Obzor. Zdr. N. 43 (3), 209-222.

Skela-Savič, B., Pagon, M., 2008. Individual involvement in health care organizations: differences between professional groups, leaders and employees. Stress Health 24 (1), 15323005. 10.1002/smi.1164

Strojan, N., Zurc, J., Skela-Savič, B., 2012. Nurses' attitudes towards research in nursing. Obzor. Zdr. Neg. 46 (1), 47-55.

Tourangeau, A.E., Cummings, G., Cranley, L.A., Ferron, E.M., Harvey, S., 2010. Determinants of hospital nurse intention to remain employed: Broadening our understanding. J. Adv. Nurs. 66 (1), 22-32. http://dx.doi.org/10.1111/j.1365-2648.2009.05190.x.

Vanlaere, L., Gastmans, C., 2007. Ethics in Nursing Education: Learning to reflect on care practices. Nurs. Ethics 14 (6), 758-766. http://dx.doi.org/10.1177/0969733007082116

Waldock, J., 2010. Facilitating student learning in clinical practice. Nurs. N. Z. 16 (1), 14-16.

Wilkes, Z., 2006. The student-mentor relationship: a review of the literature. Nurs. Stand. 20 (37), 42-47.

Worthington, M., Salamonson, Y., Weaver, R., Cleary, M., 2013. Predictive validity of the Macleod Clark Professional Identity Scale for undergraduate nursing students. Nurse Educ. Today 33 (3), 187-191. http://dx.doi.org/ 10.1016/j.nedt.2012.01.012. 
Table 1: Demographic characteristics of respondents $(\mathrm{N}=143)$

\begin{tabular}{|l|c|c|}
\hline Demographic characteristics & Number of respondents (N) & Percentage of respondents (\%) \\
\hline Age & 4 & 2.8 \\
\hline $18-25$ years & 44 & 30.8 \\
\hline $26-33$ years & 34 & 23.8 \\
\hline 41-40 years & 39 & 27.3 \\
\hline 49 years and over & 19 & 13.3 \\
\hline No data & 3 & 2.1 \\
\hline Level of education & 5 & 3.5 \\
\hline Secondary school education & 9 & 6.3 \\
\hline Short-term higher vocational education & 120 & 83.9 \\
\hline Professional higher education & 7 & 4.9 \\
\hline Bachelor's degree & 2 & 1.4 \\
\hline Master's degree & & 0.7 \\
\hline Period of employment as RN & 1 & 30.1 \\
\hline Less than 1 year & 43 & 35.4 \\
\hline 1-5 years & 35 & 43.4 \\
\hline 6-10 years & 62 & 1.4 \\
\hline Over 10 years & 2 & 16.1 \\
\hline No data & & 25.9 \\
\hline Place of employment & 23 & 52.4 \\
\hline Community health center & 37 & 1.4 \\
\hline General hospital & 75 & 4.2 \\
\hline Tertiary care center & 2 & \\
\hline Nursing home & 6 & \\
\hline No data & & \\
\hline & & \\
\hline
\end{tabular}

Table 2: Respondents' opinions on professional development

\begin{tabular}{|l|c|c|c|c|c|}
\hline Statements* & \multirow{2}{*}{$\mathrm{N}$} & $\mathrm{M}$ & $\mathrm{S}$ & \multicolumn{2}{|c|}{ Factor analysis } \\
\cline { 5 - 6 } & & & & $F 1$ & $F 2$ \\
\hline Professional development influences my job performance and results. & 140 & 4.0 & 0.7 & 0.816 & 0.166 \\
\hline $\begin{array}{l}\text { Professional development influences my ability to take initiative and } \\
\text { my capacity for innovation. }\end{array}$ & 139 & 4.0 & 0.6 & 0.804 & 0.292 \\
\hline $\begin{array}{l}\text { Possible longer absences from home represent an obstacle in my } \\
\text { professional development. }\end{array}$ & 139 & 3.5 & 0.9 & 0.026 & 0.142 \\
\hline $\begin{array}{l}\text { Professional development influences my satisfaction with the work I } \\
\text { perform. }\end{array}$ & 138 & 3.8 & 0.7 & 0.629 & 0.459 \\
\hline Professional development increases my self-confidence. & 139 & 4.1 & 0.7 & 0.439 & 0.827 \\
\hline $\begin{array}{l}\text { Overall, professional development and continuous education } \\
\text { significantly influence the development of nursing. }\end{array}$ & 139 & 4.3 & 0.6 & 0.458 & 0.466 \\
\hline
\end{tabular}

*5-point Likert scale was employed ( 1 = Strongly Disagree, $5=$ Strongly Agree), M = Mean, SD = Standard Deviation, $\mathrm{F}=$ Factor 
Table 3: Opinions on ethical behavior in mentoring students

\begin{tabular}{|c|c|c|c|c|c|}
\hline & \multirow{2}{*}{$\mathrm{N}$} & \multirow{2}{*}{ M } & \multirow{2}{*}{ SD } & \multicolumn{2}{|c|}{ Factor analysis } \\
\hline Statements* & & & & $F 1$ & $F 2$ \\
\hline $\begin{array}{l}\text { During their nursing practice, I inform students of the importance of adhering to } \\
\text { provisions of the Code of Ethics for Nurses and Nurse Assistants of Slovenia. }\end{array}$ & 138 & 3.8 & 1.0 & 0.172 & 0.821 \\
\hline I inform students of the current acts and declarations governing the area of ethics. & 139 & 3.3 & 1.0 & 0.092 & 0.873 \\
\hline $\begin{array}{l}\text { Students should be reminded to transfer the provisions and principles defined in the } \\
\text { Code of Ethics, acts, and declarations into practice and their direct work with } \\
\text { patients. }\end{array}$ & 136 & 3.6 & 1.0 & 0.180 & 0.706 \\
\hline $\begin{array}{l}\text { During their nursing practice in a clinical setting, students must be aware of the } \\
\text { importance of protecting patients' health and medical information. }\end{array}$ & 139 & 4.7 & 0.6 & 0.533 & 0.204 \\
\hline $\begin{array}{l}\text { In implementing nursing interventions, I respect the patients' right to decline the } \\
\text { involvement of nursing students in the intervention. }\end{array}$ & 139 & 4.7 & 0.5 & 0.686 & 0.108 \\
\hline I am aware that ethical dilemmas should be resolved together with nursing students. & 139 & 4.4 & 0.7 & 0.673 & 0.351 \\
\hline $\begin{array}{l}\text { Unethical behavior of nurses has a detrimental effect on the development of ethical } \\
\text { values in students. }\end{array}$ & 139 & 4.5 & 0.6 & 0.787 & 0.174 \\
\hline Clinical mentors serve as role models for students. & 138 & 4.7 & 0.5 & 0.806 & 0.014 \\
\hline Nurses' behavior influences students' professional development. & 139 & 4.5 & 0.6 & 0.723 & 0.103 \\
\hline
\end{tabular}

*5-point Likert scale was employed (1 = Strongly Disagree, $5=$ Strongly Agree), M = Mean, SD = Standard

Deviation, $\mathrm{F}=$ Factor

Table 4: Correlation analysis results for independent variables and factors obtained with factor analysis

\begin{tabular}{|c|c|c|c|c|}
\hline & F 1 & F 2 & F 3 & F 4 \\
\hline Age & 0.116 & 0.007 & $0.202^{*}$ & $0.273^{* *}$ \\
\hline Level of education & 0.071 & 0.020 & $0.187^{*}$ & 0.061 \\
\hline Position of employment & -0.076 & 0.023 & -0.083 & 0.094 \\
\hline Place of employment & 0.101 & -0.010 & -0.114 & -0.065 \\
\hline Communication with patients & -0.024 & 0.046 & -0.020 & -0.007 \\
\hline Communication with families of patients & -0.020 & 0.052 & -0.077 & 0.011 \\
\hline Record keeping & -0.086 & $-0.240^{* *}$ & 0.009 & -0.024 \\
\hline Health care education & 0.088 & 0.124 & 0.082 & 0.159 \\
\hline Mentorship of students & $0.174^{*}$ & -0.076 & -0.012 & $0.239^{* *}$ \\
\hline Research & 0.114 & 0.062 & -0.080 & 0.058 \\
\hline Other & -0.088 & 0.031 & -0.005 & -0.162 \\
\hline Career development plan agreed on with the employer & $-0.194^{*}$ & -0.044 & -0.147 & $-0.204^{*}$ \\
\hline $\begin{array}{l}\text { Number of training/education days received over the past three } \\
\text { years }\end{array}$ & 0.089 & -0.020 & -0.015 & 0.167 \\
\hline Education in ethics & 0.107 & -0.079 & $0.189^{*}$ & 0.009 \\
\hline Education in legislation & 0.134 & -0.047 & 0.143 & $0.191^{*}$ \\
\hline Education in communication skills & 0.119 & 0.091 & 0.157 & -0.063 \\
\hline Education in research & 0.135 & 0.056 & 0.086 & 0.076 \\
\hline
\end{tabular}




\begin{tabular}{|c|c|c|c|c|}
\hline Education/training in own area of work & 0.089 & -0.041 & 0.046 & 0.042 \\
\hline Education in information science & -0.089 & 0.001 & 0.032 & 0.084 \\
\hline Reporting on education/training programs & -0.001 & 0.166 & 0.035 & -0.061 \\
\hline Mentor preparation programs & 0.132 & 0.147 & $0.171^{*}$ & 0.063 \\
\hline Self-assessment of knowledge in ethics & $0.238^{* *}$ & 0.034 & $0.217^{*}$ & $0.412^{* * *}$ \\
\hline $\begin{array}{l}\text { Self-assessment of the capability to develop ethical values in } \\
\text { nursing students }\end{array}$ & $0.295^{* *}$ & 0.124 & $0.256^{* *}$ & $0.362^{* *}$ \\
\hline $\begin{array}{l}\text { Influence of career advancement on the level of job } \\
\text { satisfaction }\end{array}$ & $-0.421^{* *}$ & $-0.365^{* *}$ & -0.006 & -0.078 \\
\hline $\begin{array}{l}\text { Importance of research and learning on the development of } \\
\text { nursing }\end{array}$ & $-0.279^{* *}$ & $-0.291^{* *}$ & $-0.215^{*}$ & $-0.179^{*}$ \\
\hline Competence in work performance & -0.143 & -0.100 & -0.153 & -0.134 \\
\hline \multicolumn{5}{|l|}{ **Correlation is significant at the 0.01 level (2-tailed). } \\
\hline \multicolumn{5}{|c|}{$\begin{array}{l}\text { F1-Professional development and its positive effects on job performance, F2-Increased self-confidence and other } \\
\text { effects of professional development, F3-Responsibility for the development of ethical values in nursing students, F4- } \\
\text { Applying ethical principles and norms into practice. }\end{array}$} \\
\hline
\end{tabular}


Table 5: Linear regression analysis

\begin{tabular}{|c|c|c|c|c|c|c|}
\hline \multicolumn{2}{|r|}{$\begin{array}{l}\text { Dependent } \\
\text { Variables }\end{array}$} & Characteristics & $b$ & $\mathrm{SE}_{b}$ & $\beta$ & $p$ \\
\hline \multirow{9}{*}{ 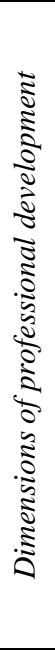 } & \multirow{6}{*}{$\begin{array}{l}\left(R^{2}=0.256\right) \\
\text { Professional } \\
\text { development } \\
\text { and its } \\
\text { positive } \\
\text { effects on job } \\
\text { performance }\end{array}$} & Time spent mentoring students & 0.010 & 0.009 & 0.088 & 0.289 \\
\hline & & Career development plan agreed on with the employer & -0.198 & 0.097 & -0.160 & 0.043 \\
\hline & & Self-assessed knowledge of ethics & -0.018 & 0.134 & -0.016 & 0.891 \\
\hline & & $\begin{array}{l}\text { Self-assessed capability of developing ethical values in } \\
\text { nursing students }\end{array}$ & 0.216 & 0.128 & 0.192 & 0.093 \\
\hline & & $\begin{array}{l}\text { The influence of career advancement on the level of job } \\
\text { satisfaction }\end{array}$ & -0.485 & 0.116 & -0.335 & $<0.001$ \\
\hline & & $\begin{array}{l}\text { Research and learning contribute towards the development } \\
\text { of nursing }\end{array}$ & -0.324 & 0.142 & -0.182 & 0.024 \\
\hline & \multirow{3}{*}{$\begin{array}{l}\left(R^{2}=0.188\right) \\
\text { Increased } \\
\text { self- } \\
\text { confidence } \\
\text { and other } \\
\text { effects of } \\
\text { professional } \\
\text { development }\end{array}$} & Time spent for record keeping & -0.013 & 0.006 & -0.184 & $\mathbf{0 . 0 2 8}$ \\
\hline & & $\begin{array}{l}\text { The influence of career advancement on the level of job } \\
\text { satisfaction }\end{array}$ & -0.450 & 0.119 & -0.314 & $<0.001$ \\
\hline & & $\begin{array}{l}\text { Research and learning contribute towards the development } \\
\text { of nursing }\end{array}$ & -0.297 & 0.151 & -0.168 & 0.051 \\
\hline \multirow{14}{*}{ 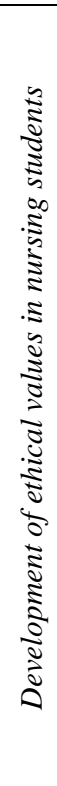 } & \multirow{7}{*}{$\begin{array}{l}\left(R^{2}=0.145\right) \\
\text { Responsibility } \\
\text { for the } \\
\text { development } \\
\text { of ethical } \\
\text { values in } \\
\text { nursing } \\
\text { students }\end{array}$} & Age & 0.137 & 0.073 & 0.162 & 0.064 \\
\hline & & Level of education & 0.329 & 0.140 & 0.195 & $\mathbf{0 . 0 2 0}$ \\
\hline & & Education in ethics & 0.291 & 0.172 & 0.142 & 0.094 \\
\hline & & $\begin{array}{l}\text { Participation in mentor preparation programs over the past } \\
\text { three years }\end{array}$ & 0.101 & 0.119 & 0.074 & 0.397 \\
\hline & & Self-assessed knowledge of ethics & 0.000 & 0.145 & 0.000 & 0.998 \\
\hline & & $\begin{array}{l}\text { Self-assessed capability of developing ethical values in } \\
\text { nursing students }\end{array}$ & 0.194 & 0.140 & 0.165 & 0.169 \\
\hline & & $\begin{array}{l}\text { Research and learning contribute towards the development } \\
\text { of nursing }\end{array}$ & $\begin{array}{c}- \\
0.348 \\
\end{array}$ & 0.153 & -0.187 & $\mathbf{0 . 0 2 4}$ \\
\hline & \multirow{7}{*}{$\begin{array}{l}\left(R^{2}=0.212\right) \\
\text { Applying } \\
\text { ethical } \\
\text { principles } \\
\text { and norms } \\
\text { into practice }\end{array}$} & Age & 0.132 & 0.071 & 0.157 & 0.067 \\
\hline & & Time spent mentoring students & 0.012 & 0.010 & 0.106 & 0.222 \\
\hline & & Career development plan agreed on with the employer & -0.123 & 0.107 & -0.095 & 0.253 \\
\hline & & Education in legislation & 0.112 & 0.188 & 0.050 & 0.553 \\
\hline & & Self-assessed knowledge of ethics & 0.303 & 0.144 & 0.251 & $\mathbf{0 . 0 3 7}$ \\
\hline & & $\begin{array}{l}\text { Self-assessed capability of developing ethical values in } \\
\text { nursing students }\end{array}$ & 0.086 & 0.139 & 0.074 & 0.535 \\
\hline & & $\begin{array}{l}\text { Research and learning contribute towards the development } \\
\text { of nursing }\end{array}$ & $\begin{array}{c}- \\
0.301\end{array}$ & 0.148 & -0.162 & $\mathbf{0 . 0 4 4}$ \\
\hline
\end{tabular}

